\title{
Penerapan Good Governance dalam Pengelolaan Keuangan Desa Kuala Alam Kecamatan Bengkalis
}

\author{
Affiliation: \\ Politeknik Negeri Bengkalis, Indonesia \\ *Correspondence: \\ endang.sri@polbeng.ac.id \\ This Article is Avalilable in: \\ https://journal.umy.ac.id/index.php/jat \\ i/article/view/10895 \\ DOI: \\ https://doi.org/10.18196/jati.v4i2.108 \\ 95 \\ Citation: \\ Wahyuni, E., \& Fatmawati, F. (2021). \\ Penerapan Good Governance dalam \\ Pengelolaan Keuangan Desa Kuala \\ Alam Kecamatan Bengkalis. Jati: Jurnal \\ Akuntansi Terapan Indonesia, 4(2), \\ 165-177.
}

Article History
Received:
15 March 2021
Reviewed:
24 June 2021
Revised:
26 Agustus 2021
Accepted:
30 September 2021
Topic Article:
Sector Public Accounting

\author{
Endang Sri Wahyuni*, Fatmawati
}

\begin{abstract}
:
This study aimed to reveal the application of the principles of participation, responsibility, accountability, and transparency in financial management in Kuala Alam Village, Bengkalis District, Bengkalis Regency. This qualitative research was conducted through a case study, and data collection was carried out through observation, interviews, and documentation. The results indicated that the Kuala Alam village government has been responsible to the community, the BPD, the Regent to carry out the work plan prepared at the village meeting. Openness in obtaining information to the public was through billboards containing information about the APBDesa. At the planning, the Kuala Alam village officials had already held a public discussion involving the community. At the implementation stage, the Head of Section and the Head of Office had done the tasks well and under applicable standards and rules. In the administrative stage, the village government had carried out bookkeeping in an orderly manner. Meanwhile, at the reporting and accountability stage, the Kuala Alam village officials had submitted a report to the Regent through the Camat and BPD. This research implied that both the community and the Kuala Alam Village officials could cooperate in supervising village financial management to realize good governance.
\end{abstract}

Keywords: Management, Participation, Responsibility, Accountability, Transparency

Abstrak:

Penelitian bertujuan untuk mengungkap penerapan prinsip partisipasi, responsibilitas, akuntabilitas, dan transparansi dalam pengelolaan keuangan di Desa Kuala Alam Kecamatan Bengkalis Kabupaten Bengkalis. Penelitian kualitatif ini dilakukan dengan pendekatan studi kasus, dan pengumpulan data dilakukan melalui observasi, wawancara, dan dokumentasi. Hasil penelitian ini menunjukkan bahwa Pemerintah desa Kuala Alam bertanggungjawab kepada masyarakat, BPD, Bupati untuk melaksanakan rencana kerja kegiatan yang telah disusun pada saat musyawarah desa. Keterbukaan dalam mendapatkan informasi yang telah disusun disampaikan kepada masyarakat lewat baliho yang berisi informasi tentang APBDesa. Pada saat perencanaan, pemerintah desa Kuala Alam sudah melakukan Musyawarah Perencanaan Pembangunan melibatkan masyarakat. Pada tahap pelaksanaan, Kasi dan Kaur sudah bertanggungjawab atas tugas yang telah diberikan yaitu sesuai dengan standar dan aturan yang berlaku. Dalam tahap penatausahan pemerintah desa sudah melakukan pembukuan dengan tertib. Sedangkan pada tahap pelaporan dan pertanggungjawaban pemerintah desa Kuala Alam sudah memberikan laporan kepada Bupati melalui Camat dan BPD. Implikasi penelitian ini yaitu baik masyarakat maupun Pemerintah Desa Kuala Alam bisa saling bekerjasama dalam melakukan pengawasan terhadap pengelolaan keuangan desa agar tercipta Good Governance.

Kata Kunci: Pengelolaan, Partisipasi, Responsibilitas, Akuntabilitas, Transparansi 


\section{PENDAHULUAN}

Undang-undang Nomor 6 Tahun 2014 mengatur tentang penataan desa, yang bertujuan untuk mewujudkan efektivitas penyelenggaraan pemerintahan desa, meningkatkan kesejahteraan masyarakat desa, meningkatkan kualitas pelayanan publik, serta meningkatkan kualitas tata kelola pemerintahan desa, dan daya saing desa (Pramata, 2018). Pengelolaan keuangan desa juga diatur Dalam Peraturan Menteri Dalam Negeri Nomor 20 Tahun 2018 perubahan dari Peraturan Menteri Dalam Negeri Nomor 113 Tahun 2014 tentang Pengelolaan Keuangan Desa. Idealnya, dalam menerapkan pengelolaan keuangan desa harus memenuhi prinsip-prinsip good governance yang terdiri dari akuntabilitas, transparansi, responsibilitas dan partisipasi, yang dimaksud agar aparatur desa dapat berprilaku sesuai dengan etika atau peraturan yang berlaku dengan memberi kewajiban atas pengelolaan sumber daya publik kepada pihak pemberi mandate (principle) atau pihak yang berkepentingan (Mahmudi, 2015).

Penerapan prinsip good governance dalam pengelolaan keuangan desa harus dilaksanakan oleh aparatur desa bersama masyarakat. Pemerintah yang tidak transparan akan mengkibatkan masyarakat tidak ikut berpartisipasi didalam pengelolaan keuangan desa. Akuntabilitas dan transparansi ini tentunya harus benar-benar diterapkan dan mendapatkan perhatian yang serius dari semua stakeholder yang ada di Desa, baik itu pemerintah maupun masyarakat serta lembaga swadaya yang ada di Desa guna tercapainya kemandirian desa. Hal ini ditegaskan oleh Peraturan Menteri Dalam Negeri Nomor 20 Tahun 2018 tentang Pengelolaan Keuangan Desa yang didalamnya terdapat asas pengelolaan keuangan bahwa keuangan desa dikelola berdasarkan asas-asas transparan, akuntabel, partisipatif serta dilakukan dengan tertib dan disiplin anggaran.

Asas-asas dalam pengelolaan keuangan desa merupakan wujud dari kewajiban seorang untuk mempertanggungjawaban pengelolaan dan pengendalian sumber daya dan pelaksanaan kebijakan yang dipercayakan kepadanya dalam rangka pencapaian tujuan yang telah ditetapkan. Dalam pengelolaan keuangan desa sebagaimana diatur dalam Peraturan Menteri Dalam Negeri Nomor 20 Tahun 2018 tentang Pengelolaan Keuangan Desa menyatakan bahwa Kepala Desa memiliki tanggungjawab untuk melaporkan laporan realisasi anggaran desa kepada Bupati. Selain itu, Kepala Desa juga bertanggungjawab untuk mengendalikan Perangkat Desa dalam merealisasikan anggaran APBDesa yang telah direncanakan Bendahara, Sekretaris Desa dan Kepala Seksi juga bertanggungjawab kepada Kepala Desa atas Pengelolaan Keuangan Desa (Astriandy, 2018). Asas akutabel menurut Badan Pengawasan Keuangan dan Pembangunan (2015) bahwa yang menentukan setiap kegiatan dan hasil akhir kegiatan penyelenggaraan pemerintahan desa harus dapat dipertanggungjawabkan kepada masyarakat desa sesuai dengan ketentuan Peraturan Perundang-undangan. Oleh karena itu, pemerintah desa harus bisa menerapkan prinsip akuntabilitas didalam tata kelola pemerintahannya. Sejalan dengan penelitian yang dilakukan oleh Anggriani, N., Iskandar, D., \& Nurodin, I. (2019) yang menyatakan bahwa dengan adanya penggunaan Sistem Keuangan Desa untuk pengelolaan Keuangan Pemerintah Desa seperti Buku Kas Umum, Buku Pembantu Pajak, Laporan Realisasi APBDes akan menjadikan pelaporan keuangan desa lebih akuntabel. Selain itu, akuntabilitas akan menciptakan pengawasan yang efektif didasarkan atas distribusi dan keseimbangan kekuasaan, masyarakat tidak hanya memiliki hak untuk mengetahui keuangan desa, tetapi juga berhak dalam menuntut pertanggungjawaban atas perencanaan serta pelaksanaan program kegiatan yang dianggarkan dengan menggunakan keuangan desa (Astriandy, 2018). Penerapan prinsip akuntabilitas juga akan meningkatkan tranparansi dari kinerja pemerintah desa secara teratur dan tepat waktu serta benar dan dapat diandalkan. 
Transparansi memberikan informasi pengelolaan yang terbuka dan jujur kepada masyarakat berdasarkan pertimbangan bahwa masyarakat memiliki hak untuk mengetahui secara terbuka dan menyeluruh atas pertanggungjawaban pemerintah dalam pengelolaan sumber daya yang dipercayakan kepadanya dan ketaatannya pada Peraturan Perundangundangan (Sangki dkk, 2017). Dengan adanya keterbukaan informasi publik, diharapkan masyarakat dapat semakin aktif terlibat dalam proses pembuatan kebijakan publik. Mulai dari tahap perencanaan, implementasi, pemantauan, hingga evaluasi kebijakan. Keterlibatan masyarakat dalam pembuatan keputusan baik secara langsung maupun tidak langsung melalui lembaga perwakilan yang dapat menyalurkan aspirasinya. Partisipasi tersebut dibangun atas dasar kebebasan berasosiasi dan berbicara serta berpartisipasi secara konstruktif (Mardiamso, 2009).

Penelitian yang dilakukan oleh Andini (2018) tentang Penerapan Akuntabilitas dan Transparansi Pengelolaan Keuangan Desa yang dilakukan di Desa Sindoharjo Kecamatan Ngaglik Kabupaten Sleman menunjukkan hasil penelitian bahwa pemerintah desa Sindoharjo telah menerapkan prinsip akuntabilitas dan prinsip transparansi dalam pengelolaan keuangan desa. Pemerintah desa Sindoharjo bertanggungjawab kepada masyarakat, BPD, dan Bupati untuk melaksanakan rencana kegiatan yang telah disusun dalam musyawarah desa. Keterbukaan akses informasi rencana kegiatan yang telah disusun disampaikan kepada masyarakat luas dengan pemasangan baliho yang berisi informasi APBDes. Pada tahap pelaksanaan tim pelaksa kegiatan bertangungjawab atas pelaksanaan program kerja. Masyarakat ikut dilibatkan dalam pelaksanaan dan informasi mengenai detail kegiatan diberikan dalam bentuk papan informasi proyek. Dalam tahap pelaporan dan pertanggungjawaban pemerintah desa bertanggungjawaban untuk memberikan pelaporan secara berkala kepada Badan Permusyawaratan Desa dan Bupati. Bendahara Desa Sindoharjo juga mengaplikasikan Siskeudes dalam pembuatan laporan desa. Keterbukaan informasi bagi masyarakat luas diberikan melalui pemasangan informasi penggunaan dana desa ditempat-tempat startegis. Begitu juga halnya penelitian yang dilakukan oleh Anggriani, N., Iskandar, D., \& Nurodin, I. (2019) tentang Penerapan Prinsip Akuntabilitas dan Transparansi Dalam Pengelolaan Anggaran Pendapatan dan Belanja Desa bahwa Pengelolaan pendapatan dan Anggaran Desa dari tahap Perencanaan, Implementasi, Administrasi, Pelaporan dan Akuntabilitas secara luas sesuai dengan Peraturan Menteri Dalam Negeri No. 113 tahun 2014 tentang Manajemen Keuangan, walaupun ada beberapa hal dalam Perencanaan, Implementasi, Administrasi, Pelaporan dan Akuntabilitas masih belum sesuai dengan peraturan yang berlaku dikarenakan sumber daya manusia yang kurang mendukung.

Selain itu, Penelitian yang dilakukan oleh Astriandy (2018) tentang Penerapan Good Goverment Governance dalam pengelolaan keuangan desa di Desa parit baru Kecamatan Sungai Raya Kabupaten Kubu Raya yang menunjukan bahwa dari 9 prinsip good goverment governance terdapat 6 prinsip yang telah diterapkan yaitu prinsip tegaknya supermasi hukum, peduli terhadap masyarakat, berorentasi pada konsesus, efesien dan efektif, sementara 4 prinsip sudah diterapkan tetapi belum sepenuhnya yaitu partisipasi masyarakat, transparansi, akuntabilitas dan responsibilitas. Dari pembahasan tersebut menunjukkan bahwa belum sepenuhnya prinsip dari good govermant governance dapat diterapkan dalam pengelolaan keuangan Desa tersebut.

Kemudian penelitian yang dilakukan oleh Ferarow, N. \& Suprihanto, J. (2018) tentang Implementasi Pengelolaan Keuangan Desa Sumberadi dan Tlogoadi di Kabupaten Sleman Evaluasi Praktik Transparansi dan Akuntabilitas. Hasil penelitian menunjukkan bahwa terdapat dinamika dalam pengelolaan keuangan desa. Desa Sumberadi telah melaksanakan pengelolaan keuangan desa sesuai dengan prinsip transparansi dan akuntabilitas. Akan tetapi, Desa Tlogoadi belum menerapkan pengelolaan keuangan desa dengan transparan dan akuntabel. Terdapat kendala yang dihadapi desa Tlogoadi, diantaranya belum 
efektifnya pembinaan terhadap aparatur desa, kurangnya pengawasan, kurangnya personil, dan kurangnya pemahaman aparatur desa terhadap peraturan yang berlaku.

Desa Kuala Alam merupakan desa pemekaran dari Desa Sungai Alam pada tahun 2014 yang terletak pada Kecamatan Bengkalis Kabupaten Bengkalis. Kurangnya akuntabilitas tranparansi serta tanggungjawab atas kinerja yang telah diberikan menjadi permasalahan yang terjadi pada sistem pemerintahan desa tersebut. Fenomena yang terjadi di dalam pelaksanaan program-program pemerintah Desa Kuala Alam adalah masih banyak dijumpai penyimpangan dari pihak-pihak terkait yang mencerminkan lemahnya penerapan Prinsipprinsip good governance. Kurangnya respon atau daya tanggap dari pemerintah desa dan aparat Desa Kuala Alam untuk mengenali kebutuhan masyarakat masih kurang. Kemudian dalam hal penyusunan agenda dan prioritas pelayanan, pembangunan serta programprogram kegiatan yang terkait dengan pelayanan publik yang ada di Desa Kuala Alam masih belum tertata dengan baik. Selain itu, kurangnya partisipasi masyarakat secara aktif terhadap pelaksanaan kegiatan desa menyebabkan tidak adanya bentuk laporan pertanggungjawaban dari pihak aparat Desa kepada masyarakat setempat karena lemahnya kontrol dari masyarakat sendiri, sehingga proses transparansi dan akuntabilitas dari pemerintah tidak berjalan dengan baik karena disatu sisi masyarakat tidak mempunyai informasi tentang program kegiatan yang di laksanakan oleh desa Kuala Alam.

Selain itu, masih adanya keluhan yang disampaikan oleh masyarakat terhadap birokrasi di Desa Kuala Alam yang terkait dengan kualitas pelayanan dari birokrasi masih dirasakan belum memenuhi harapan masyarakat. Kemudian, Belum maksimalnya tugas BPD dalam penyebaran informasi pelayanan secara akurat kepada masyarakat, dan tidak adanya wadah untuk masyarakat mendapatkan informasi. Serta hak-hak yang dimiliki masyarakat sering kali tidak di perhatikan dan masyarakat pun menjadi tidak tahu akan perencanaan desa ke depan karena hak dari masyarakat tidak berfungsi sehingga konsensus atau musyawarah antara masyarakat dan pemerintah itu tidak berjalan sesuai harapan dalam mewujudkan good governance.

Untuk mewujudkan tata kelola pemerintahan yang baik dalam pengelolaan keuangan desa berdasarkan teori dan peneliti terdahulu diatas, jadi penulis ingin melihat penerapan prinsip good governace disalah satu desa yang ada di Kecamatan Bengkalis Kabupaten Bengkalis yaitu Desa Kuala Alam. Adapun keterbaruan dari penelitian ini adalah pada penerapan prinsip good governace yaitu responsibilitas dan partisipasi, karena beberapa penelitian yang sudah dilakukan oleh Ferarow, N. \& Suprihanto, J. (2018), Andini (2018), dan Anggriani, N., Iskandar, D., \& Nurodin, I. (2019) hanya terkait dengan penerapan akuntabilitas dan transparansi Pengelolaan Keuangan Desa sehingga peneliti ingin mengembangkan penelitian ini lebih luas lagi. Adapun tujuannya untuk mengetahui Penerapan Prinsip Responsibilitas, Akuntabilitas, Transparansi dan Partisipasi Pada Tahap Perencanaan, Pelaksanaan, Penatausahaan, Pelaporan dan Pertanggungjawaban dalam pengelolaan keuangan desa.

\section{Pengelolaan Keuangan Desa}

Menurut Pasal 71 Undang-Undang Nomor 6 tahun 2014 tentang desa, Keuangan desa adalah semua hak dan kewajiban Desa yang dapat dinilai dengan uang serta segala sesuatu berupa uang dan barang berhubungan dengan pelaksanaan hak dan kewajiban Desa. Hak dan kewajiban menimbulkan Pendapatan, belanja, pembiayaan, dan pengelolaan keuangan Desa. Dalam Peraturan Menteri Dalam Negeri Nomor 20 Tahun 2018 Pengelolaan Keuangan Desa adalah keseluruhan kegiatan yang meliputi perencanaan, pelaksanaan, penatausahaan, pelaporan, dan pertanggungjawaban keuangan desa. Setiap tahapan proses pengelolaan keuangan desa tersebut memiliki aturan-aturan yang harus dipahami dan dilaksanakan sesuai dengan batasan waktu yang telah ditentukan (Badan Pemeriksaan Keuangan). Dalam Peraturan Menteri Dalam Negeri 
Nomor 20 tahun 2018 Pasal 30 pengelolaan keuangan desa dilakukan dengan basis kas basis kas merupakan pencatatan transaksi pada saat kas diterima atau dikeluarkan dari rekening kas desa. Pengelolaan keuangan desa dapat dilakukan dengan menggunakan sistem informasi yang dikelola Kementerian Dalam Negeri.

Tahapan pengelolaan keuangan desa tidak akan berjalan tanpa adanya tata pemerintahan desa yang baik. Oleh karena itu, peran serta pihak-pihak di luar pemerintah desa dan Badan Permusyawaratan Desa (BPD), seperti: tokoh desa, tokoh agama, perwakilan dari kaum perempuan, perwakilan dari kaum petani, perwakilan dari masyarakat miskin dan lainnya perlu dilibatkan dalam proses pengelolaan keuangan desa. Akuntabilitas keuangan desa tidak hanya bersifat horisontal antara pemerintah desa dengan Badan Musyawarah Desa (BPD), tetapi juga harus bersifat vertikal antara kepala desa dengan masyarakat desa dan atasan kepala desa. Dokumen publik tentang pengelolaan keuangan desa harus dapat diakses oleh masyarakat desa, serta tidak diskriminasi terhadap satu golongan tertentu terkait dengan pengelolaan keuangan desa (Yuliansyah \& Rusmianto, 2016).

\section{Asas Pengelolaan Keuangan Desa}

Menurut Bihamding (2019:62) asas pengelolaan keuangan desa adalah nilai-nilai yang menjiwai dari pengelolaan keuangan desa itu sendiri yang telah ditetapkan sebagai pedoman pelaksanaannya. Sesuai Peraturan Menteri Dalam Negeri Nomor 20 Tahun 2018 tentang Pengelolaan Keuangan Desa, keuangan desa dikelola berdasarkan asas-asas yaitu: (1). Transparansi, yang mana prinsip keterbukaan memungkinkan masyarakat untuk mengetahui dan mendapat akses informasi seluas-luasnya tentang keuangan desa. Semua informasi disajikan secara terbuka dan mudah diakses oleh masyarakat sehingga tercapai tujuan yang efektif dan efisien. Asas yang membuka diri terhadap hak masyarakat untuk memperoleh informasi yang benar, jujur, dan tidak diskriminatif tentang penyelenggaraan pemerintahan desa dengan tetap memperhatikan ketentuan perundang-undangan; (2). Akuntabel, yaitu perwujudan kewajiban untuk mempertanggungjawabkan pengelolaan dan pengendalian sumberdaya dan pelaksanaan kebijakan yang dipercayakan dalam rangka pencapaian tujuan yang telah ditetapkan. Setiap kegiatan dan hasil akhir kegiatan penyelenggaraan pemerintahan desa harus dapat dipertanggungjawabkan kepada masyarakat desa sesuai ketentuan perundang-undangan. Pengelolaan keuangan dapat dipertanggungjawabkan secara hukum, terhadap hasil yang dicapai; (3). Partisipatif, artinya pengelolaan keuangan desa mengikutsertakan kelembagaan desa dan unsur masyarakat desa; (4). Tertib dan disiplin anggaran, yaitu pengelolaan keuangan desa harus mengacu pada aturan atau pedoman yang melandasinya.

\section{Good Governance}

Good Governance merupakan isu yang paling mengemukan dalam pengelolaan keuangan dan administrasi dewasa ini. Dengan meningkatnya tingkat pengetahuan masyarakat dan pengaruh globalisasi, masyarakat gencar untuk menuntut pemerintah melaksanakan penyelenggaraan pemerintahan dengan baik. Terdapat 9 (sembilan) karakteristik Good Governance, yaitu: (1). Partisipation, yaitu setiap warga negara mempunyai suara dalam pembuatan keputusan, baik secara langsung maupun melalui inter-mediasi institusi legitimasi yang mewakilkan kepentingannya; (2). Rule of law, yang mana kerangka hukum harus adil dan dilaksanakan tanpa pandang bulu, terutama hukum untuk azazi manusia; (3). Transparency, yakni transparansi dibangun atas dasar kebebasan arus informasi yang berkaitan dengan kepentingan publik secara langsung dapat diperoleh masyarakat yang membutuhkan; (4). Responciveness, sebagai lembaga-lembaga dan proses-proses harus mencoba untuk melayani setiap stakeholders; (5). Concensus orientation, artinya Good Governance menjadi perantara kepentingan yang berbeda untuk 


\author{
Wahyuni, Fatmawati \\ Penerapan Good Governance dalam Pengelolaan Keuangan \\ Desa Kuala Alam Kecamatan Bengkalis
}

memperoleh pilihan terbaik bagi kepentingan yang lebih luas baik dalam hal kebijakan maupun prosedur-prosedur; (6). Equinty, yang mana semua warga Negara, baik laki-laki maupun perempuan, mempunyai kesempatan untuk meningkatkan atau menjaga kesejahteraan mereka; (7). Effectiveness and efficiency, dalam proses-proses dan lembagalembaga menghasilkan sesuai dengan apa yang telah digariskan dengan menggunakan sumber-sumber yang tersedia sebaik mungkin; (8). Accountability, Para pembuatan keputusan dalam pemerintahan, sektor swasta dan masyarakat (civil society) bertanggung jawab kepada public dan lembaga-lembaga stakeholders; (9). Strategic Vision, yaitu para pemimpin dan publik harus mempunyai perspektif good governance dan pengembangan manusia yang luas dan jauh ke depan sejalan dengan apa yang diperlukan untuk pembangunan semacam ini.

\title{
METODE PENELITIAN
}

Penelitian ini dilakukan di desa Kuala Alam. Jenis penelitian ini yaitu pendekatan kualitatif Menurut Hikmawati (2017:18) Studi kasus menggunakan individu atau kelompok sebagai bahan studinya. Sujarweni (2014:22) juga menyatakan bahwa studi kasus merupakan penelitian mengenai manusia (dapat suatu kelompok, organisasi maupun individu), peristiwa, latar secara mendalam, tujuan dari penelitian ini mendapatkan gambaran yang mendalam tentang suatu kasus yang sedang diteliti. Triangulasi adalah metode yang digunakan dalam penelitian kualitatif untuk memeriksa dan menetapkan validitas dengan menganalisa dari berbagai perspektif. Metode ini dilakukan dengan cara membandingkan informasi atau data dengan cara yang berbeda.

Dalam penelitian ini peneliti menggunakan metode: (1). Wawancara, adapun indikator pertanyaan wawancara dilakukan dengan mengadopsi dari penelitian terdahulu serta berdasarkan peraturan yang berlaku dengan menggunakan wawancara terstruktur. Wawancara dilakukan kepada informan yang dipilih yang merupakan pihak-pihak yang ikut andil dalam proses pengelolaan keuangan desa dimulai dari tahap perencanaan hingga pertanggungjawaban diantaranya yaitu Kepala Desa, Sekretaris Desa, Bendahara Desa, Badan Permusyawaratan Desa serta Masyarakat. Wawancara yang dilakukan oleh peneliti dibantu oleh alat perekam; (2). Analisis dokumen berupa APB Desa, Buku Kas Umum, laporan pertanggungjawaban Realisasi Anggaran Pemerintah Desa, Laporan Kekayaan Milik Desa serta Rencana Pembangunan Jangka Menengah Desa (RPJMDesa), Rencana Kerja Pemerintah Desa (RKPDes). Penentuan informan dalam penelitian ini menggunakan teknik snowball sampling yaitu pemilihan informan kedua berdasarkan informasi dari informan pertama, informan ketiga berdasarkan rekomendasi informan kedua dan seterusnya. Metode ini sangat baik untuk penggunaan wawancara mendalam. Sedangkan teknik analisis data yang dilakukan adalah deskriptif.

\section{HASIL DAN PEMBAHASAN}

\section{Penerapan Prinsip Responsibilitas, Akuntabilitas, Transparansi dan Partisipasi pada Tahap Perencanaan dalam Pengelolaan Keuangan Desa}

Dalam Tahap perencanaan keuangan desa di Desa Kuala Alam diawali dengan membuat rencana pembangunan jangka menengah desa (RPJMDesa). RPJMDesa ini dibuat pada awal periode pemerintah desa atau terpilihnya Kepala Desa. RPJMDesa adalah dokumen perencanaan untuk periode 5 (lima) tahun yang memuat arah kebijakan pembangunan desa, strategi pembangunan desa dan program kerja desa dengan mengacu pada Rencana Pembangunan Jangka Menengah Daerah. RPJMDesa ini disusun agar dapat dijadikan sebagai acuan dasar pembangunan oleh pemerintah desa Kuala Alam. RPJMDesa 
berfungsi sebagai pedoman dalam membuat dokumen perencanaan tahunan yaitu rencana Kerja Pemerintah Desa (RKPDes) untuk menjamin keterkaitan dan konsistensi antara perencanaan, pelaksanaan, penatausahaan, pelaporan serta pertanggungjawaban.

Penerapan prinsip responsibilitas menurut Sjamsir (2016) berkaitan dengan pelaksanaan penilian serta standar pelaksanaan kegiatan, apakah standar yang dibuat sudah tepat dengan situasi dan kondisi yang dihadapi, dan jika sudah tepat maka pihak pemerintah desa memiliki tanggungjawab untuk mengimplementasikan sesuai peraturan yang berlaku. Responsibilitas juga berhubungan dengan kewajiban dalam melaksanakan wewenang yang diberikan. Dalam hal ini pemerintah desa Kuala Alam sudah mulai membuat RPJMDesa, RKPDes dan APBDes yang dilaksanakan oleh Kasi dan Kaur sesuai dengan tugas dan fungsi yang telah ditetapkan oleh pemerintah desa Kuala Alam. Pemerintah desa Kuala Alam sudah melakukan musrenbang desa yang dijadwalkan oleh Kecamatan setempat. Hal ini seperti yang diungkapkan oleh Sekdes pada tanggal 07 April 2020, pukul 08.00 WIB sebagai berikut:

"Jadi untuk musrenbang ini dilakukan oleh BPD dan jadwalnya ditentuka oleh Kecamatan setempat. Setelah itu disusunlah RKPDes untuk membuat RAPBDes. Jadi pemerintah desa Kuala Alam sudah tepat waktu untuk melakukan tugas tersebut".

Selanjutnya ditambahkan oleh BPD Kuala Alam tanggal 06 April 2020, 14.00 WIB, mengatakan:

"Jadi disaat musrenbang desa, pemerintah desa akan membuat daftar hadir dan dilengkapi berita acara yang dijadikan administrasi untuk diserahkan ke kantor Camat setempat"

Begitu juga halnya dengan penerapan prinsip Akuntabilitas bahwa dalam pelaksanaannya sesuai Permendagri No. 20 Tahun 2018, kepala desa yang menyelenggarakan penyusunan RPJMDesa wajib mengikutsertakan unsur masyarakat desa dan dilaksanakan dengan mempertimbangkan kondisi objektif desa, prioritas program, dan kegiatan Kabupaten/Kota. Selanjutnya Rencana Kerja Pemerintah Desa (RKPDesa) merupakan penjabaran dari RPJMDesa untuk jangka waktu 1 (satu) tahun yang memuat kerangka ekonomi desa dengan mempertimbangkan kerangka pendanaan yang dimuktahirkan, program prioritas pembangunan desa, rencana kerja dan pendanaan serta perkiraan maju, baik yang dilaksanakan langsung oleh pemerintah desa maupun yang ditempuh dengan mendorong partisipasi masyarakat dengan mengacu kepada Rencana Kerja Pemerintah Daerah (RKPD) dan RPJMDesa.

Hal ini seperti yang diungkapkan oleh Kades, Kuala Alam tanggal 06 April 2020, 08.00 WIB sebagai berikut:

"Untuk penggunaan anggaran itu ada namanya RPJMDesa (Rencana Pembangunan Jangka Menengah Desa). Dari RPJMDesa ini kita membuat pertahun namanya RKPDes (Rencana Kerja Pemerintah Desa) dari RKPDes kita membuat APBDes. Dari APBDes itu rencana keuangan dalam satu tahun bisa diselenggarakan dengan arti lain untuk RPKDes ini kita menelaah yang ada RPJMDesa"

Selain itu, BPD Kuala Alam tanggal 06 April 2020, 14.00 WIB juga mengatakan bahwa:

"Jadi untuk pemerintah desa Kuala Alam setelah kaur perencanaan membuat atau menyusun RABPDes nantik Sekdes akan memverifikasi dan diserahkan kepada Kepala 
Desa akan untuk disahkan, nanti Kepala Desa akan menyerahkan ke BPD untuk dibahas bersama"

Sedangkan pada penerapan prinsip Transparansi menunjukkan bahwa masyarakat turut dilibatkan dalam musyawarah desa dalam penyampaian aspirasi dan usulan rencana kegiatan yang akan dijadikan program kerja oleh pemerintah desa, jadi aspirasi masyarakat pada musyarawah desa akan ditampung. Musyawarah tersebut dilaksanakan untuk mendata potensi sumber daya dan permasalahan yang dialami warga disetiap tempat. Dalam pelaksanaan musrenbang desa perwakilan warga masyarakat dan lembaga-lembaga yang ada didesa dilibatkan untuk bersama-sama dengan pemerintah desa dan merencanakan kegiatan yang akan disusun menjadi program kerja tahunan pemerintah desa. Musrenbang desa juga dilaksanakan untuk membahas rencana kerja tahunan pemerintah desa atau RKPDes. Program- program yang telah disusun dalam RPJMDesa akan ditentukan skala prioritas pelaksanaannya dan dipetakan kedalam rencana kegiatan tahunan. Rencana kegiatan tahunan pemerintah atau RKPDesa ini nantinya akan dijadikan dasar pembuatan RAPBDes oleh Kaur Perencanaan. RAPBDes yang telah disusun akan disampaikan ke BPD selaku perwakilan masyarakat desa untuk disetujui. Nantinya informasi tentang APBDes yang telah disetujui Bupati akan disampaikan kepada masyarakat luas. APBDes yang sudah disetujui oleh Bupati, akan disampaikan kepada warga masyarakat dalam bentuk baliho yang akan dipasang didepan kantor desa dalam baliho tersebut akan dijabarkan rencana anggaran pendapatan dan pengeluaran pemerintah desa dalam satu tahun. Selain itu pemerintah desa Kuala Alam ingin menyampaikan dalam bentuk laporan kedalam website milik desa Kuala Alam. Hal tersebut sudah termasuk penerapan prinsip partisipatif dalam pengelolaan keuangan desa. Seperti yang diungkapkan oleh Sekdes Desa Kuala Alam, tanggal 07 April 2020, 08.00 WIB, sebagai berikut:

"Jadi tahap perencaan ini kami melibatkan masyarakat tentunya, dibuktikan dengan adanya musrenbang desa, jadi didalam musrenbang desa akan dihadirkan berbagai kalangan, misalnya, Dusun, RT, RW, Tokoh Masyarakat, Lembaga-lembaga desa, dan tentunya dihadiri juga BPD"

Kemudian Sekdes, Kuala Alam, tanggal 07 April 2020, 08.00 WIB, menambahkan:

"Jadi untuk APBDes sudah pasti rencanakan, sudah pasti juga dilaksanakan. Nah, setelah itu akan informasikan kepada warga. Salah satu cara menginformasikan yaitu dengan ditempel atau dengan membuat baliho. Yang didalam baliho itu berisi tentang rincian APBDes satu tahun mendatang"

Dari hasil penelitian dapat disimpulkan bahwa pemerintah desa kuala alam sudah melakukan perencanaan keuangan yang diawali dengan membuat rencana pembangunan jangka menengah desa (RPJMDes). Kemudian dari RPJMDes yang telah disusun, pemerintah desa membuat rencana kerja tahunan atau yang disebut rencana kerja pemerintah desa (RKPDes). RKPDes yang telah disusun akan menjadi dasar pembuatan rancangan anggaran pendapatan dan belanja desa (RAPBDes). RAPBDes yang telah disahkan oleh Bupati akan dituangkan menjadi Peraturan Desa tentang APBDes. Sehingga pada tahap ini pemerintah desa sudah melaksanakan prinsip good governance karena pemerintah desa kuala alam sudah menerapkan sesuai dengan peraturan yang berlaku. Hal ini sejalan dengan penelitian yang sudah dilakukan oleh Ferarow, N. \& Suprihanto, J. (2018), Andini (2018), dan Anggriani, N., Iskandar, D., \& Nurodin, I. (2019). 


\section{Penerapan Prinsip Responsibilitas, Akuntabilitas, Transparasi dan Partisipasi pada Tahap Pelaksanaan dalam Pengelolaan Keuangan Desa}

Keuangan desa sepenuhnya dilakukan oleh Kaur Kasi masing-masing, Kasi Kaur bertugas menganalisis semua pelaksanaan program kegiatan disetiap program pemerintah desa. Kaur Kasi akan menyusun DPA (Dokumen Pelaksanaan Anggaran), DPA tersebut berisi Rencana kegiatan dan Anggaran desa, rencana kerja kegiatan desa, rencana anggaran biaya. Kaur dan Kasi pelaksanaan kegiatan anggaran menyerahkan rancangan DPA kepada Kepala Desa melalui sekretaris desa, Sekretrais desa akan melakukan verifikasi kemudian Kepala Desa menyutujui rancangan DPA yang telah diverifikai oleh Sekretaris Desa. Kaur dan Kasi akan memberikan SPP dan Sekdes akan memberikan SPM untuk diserahkan kepada Kepala Desa untuk disahkan. Bendahara Desa akan mencairkan dana ke Bank. Hal ini sesuai dengan yang diungkapkan oleh Sekdes Kuala Alam tanggal 07 April 2020, 08.00 WIB, sebagai berikut:

"Pemerintah desa Kuala Alam sudah menerapakan Permendagri No. 20 Tahun 2018. Pelaksanaan ini dilakukan oleh Kaur dan Kasi yang ada di pemerintah desa Kuala Alam. Tanggungjawab dilakukan oleh Kasi dan Kaur oleh pemerintah desa. Jadi peran sekdes ya memonitoring kegiatan, kegiatan yang telah disusun bersama-sama akan verifikasi terlebih dahulu lalu Kades mengesahkan"

Berdasarkan hasil wawancara peneliti bahwa pada tahap pelaksanaan pengelolaan keuangan desa, pemerintah desa Kuala Alam sudah memulai pelaksanaan tersebut dengan membuat Dokumen Pelaksanaan Anggaran. Pada tahapan ini program kerja sepenuhnya merupakan tanggungjawab dari Kasi dan Kaur sebagai tim pelaksanaan kegiatan. Sekretaris Desa akan memonitoring kegiatan yang dilakukan oleh Kasi Kaur tersebut. Tim pelaksana kegiatan bertanggung jawab untuk merealisasikan program kerja yang telah disusun pemerintah desa bersama perwakilan beberapa pihak, proses pencairan dana tersebut harus menyerahkan SPP yang sudah ditandatangani oleh kepala desa. Selanjutnya pada prinsip Transparansi dan partisipasi pemerintah desa Kuala Alam sudah melibatkan masyarakat desa dalam program kerja atau kegiatan yang dilaksanakankan, hal tersebut bisa diihat dari adanya kemudahan dalam memperoleh informasi serta diikutsertakan masyarakat dalam berbagai kegiatan yang dilaksanakan oleh pemerintah desa Kuala Alam. Selain itu dalam kegiatan pembangunan desa seperti jalan, irigasi telah memasang papan informasi yang berisi rincian anggaran yang dikeluarkan oleh pemerintah desa Kuala Alam. Hal ini seperti yang diungkapkan Sekdes Kuala Alam, tanggal 07 April 2020, 08.00 WIB bahwa:

"Jadi Sekdes memonitoring kegiatan yang ada, kegiatan-kegiatan yang dilakukan oleh Kasi Kaur. Bendahara Desa akan mencairkan Anggaran setelah ada dokumen SPM dari Sekdes yang ditanda tangani oleh Kepala Desa sebagai penanggungjawab Anggaran. Setiap kegiatan tidak lepas dari kendali saya"

Begitu halnya yang diungkapkan oleh Bendahara, Kuala Alam tanggal 06 April 2020, 11.00 WIB:

"Perjalanannya seperti itu tadi, diawali dari SPP itu nanti harus ada tanda tangan pak Kades, tanda tangan Bendahara dan tanda tangan pelaksanaan kegiatan. Kemudian setelah siap semua sudah sesuai dengan RAB kemudian akan cairkan dananya".

Dari hasil wawancara serta pengamatan peneliti bahwa Pengelolaan keuangan desa tidak akan berjalan tanpa adanya tata pemerintahan desa yang baik. Oleh karena itu, 
peran serta pihak-pihak di luar pemerintah desa dan Badan Permusyawaratan Desa (BPD), seperti: tokoh desa, tokoh agama, perwakilan dari kaum perempuan, perwakilan dari kaum petani, perwakilan dari masyarakat miskin dan lainnya perlu dilibatkan dalam proses pengelolaan keuangan desa. Akuntabilitas keuangan desa tidak hanya bersifat horisontal antara pemerintah desa dengan Badan Musyawarah Desa (BPD), tetapi juga harus bersifat vertikal antara kepala desa dengan masyarakat desa dan atasan kepala desa. Dokumen publik tentang pengelolaan keuangan desa harus dapat diakses oleh masyarakat desa, serta tidak diskriminasi terhadap satu golongan tertentu terkait dengan pengelolaan keuangan desa (Yuliansyah \& Rusmianto, 2016). Hal ini seperti sejalan dengan penelitian yang dilakukan oleh Irvan (2013) menyatakan bahwa akuntabilitas dan transparansi merupakan 2 (dua) kunci utama dalam penyelenggaraan pemerintahan yang baik.

\section{Penerapan Prinsip Responsibilitas, Akuntabilitas, Transparasi dan Partisipasi pada Tahap Penatausahaan dalam Pengelolaan Keuangan Desa.}

Kegiatan penatausahaan keuangan merupakan fungsi pengendalian terhadap APBDes. Karena hasil dari penatausahaan tersebut berupa laporan yang dapat digunakan untuk pertanggungjawaban pengelolaan keuangan desa. Berdasarkan Permendagri Nomor 20 tahun 2018 tentang Pengelolaan Keuangan Desa penatausahaan keuangan dilakukan oleh kaur keuangan sebagai pelaksana fungsi Kebendaharaan. Dalam tata kelola keuangan yang baik, pencatatan dalam penatausahaan mendorong Pemerintah Desa untuk lebih akuntabel. Semua kegiatan yang berhubungan dengan aktivitas keuangan Desa dapat tersaji dalam pembukuan keuangan yang dapat dipertanggungjawabkan seperti buku kas umum, buku pembantu bank dan buku kas desa. Pembukuan keuangan tersebut akan digunakan sebagai dasar dalam pembuatan laporan keuangan Desa. Hal ini sangat terkait dengan akuntabilitas pemerintah desa kuala Alam dalam memberikan pertanggungjawaban serta menyajikannya dalam bentuk laporan keuangan kepada stakeholder, BPD serta masyarakat. Hal ini seperti yang diungkapkan Kades, tanggal 06 April 2020, 08.00 WIB sebagai berikut:

"Untuk pelaporan diakhir tahun setelah dilakukan pembukuan maka kita akan melaksankan evaluasi. pelaporan yang sudah siap akan disampaikan kepada BPD dan Bupati. Selain itu pemerintah juga menyampaikan kepada masyarakat dalam bentuk papan baliho yang dipajang didepan kantor desa. Jadi pemerintah desa Kuala Alam terbuka terhadap masyarakat yang ingin tahu tentang keuangan yang ada"

Berdasarkan hasil wawancara dan pengamatan peneliti dalam penerapan prinsip Responsibilitas, Akuntabilitas, Transparasi dan Partisipasi menunjukkan bahwa Bendahara desa Kuala Alam sudah melakukan pencatatan keuangan desa yang dibuktikan dengan melakukan pencatatan setiap penerimaan dan pengeluaran serta melakukan tutup buku setiap akhir bulan secara tertib. Kemudian Bendahara Desa melakukan pencatatan atas seluruh penerimaan dan pengeluaran dalam Buku Kas Umum untuk yang bersifat tunai. Sedangkan transaksi penerimaan dan pengeluaran yang melalui bank/transfer dicatat dalam Buku Bank. Buku Kas Pembantu Pajak digunakan oleh Bendahara Desa Kuala Alam untuk mencatat penerimaan uang yang berasal dari pungutan pajak dan mencatat pengeluaran berupa penyetoran pajak ke kas Negara. Hal ini seperti yang diungkapkan Bendahara Kuala Alam, tanggal 06 April 2020, 11.00 WIB sebagai berikut:

"Jadi Desa Kuala Alam sudah menjalankan berdasarkan Permendagri terbaru. Untuk akuntabilitas tentunya selesai melakukan pembukuan maka kami akan melaksanakan pemasangan baliho yang ditempel didepan kantor desa Kuala Alam" 
Narasumber lainnya menambahkan oleh Sekdes Kuala Alam, tanggal 07 April 2020, 08.00 WIB:

"Penerapan transparansi ini diterapkan pada saat pelaksanaan karna disitu keuangan desa dikeluarkan jadi masih berupaya agar masyarakat desa itu peduli dan ambil tau dalam pengawasan keuangan desa"

Sekdes Kuala Alam, tanggal 07 April 2020, 08.00 WIB menambahkan:

"Jadi tahap penatausahaan ini merupakan tugas dari Kaur Keuangan yang merangkup Bendahara Desa. Pada saat penatausahaan ini Bendahara Desa cuma melakukan pembukuan, melakukan pencatatan setiap kegiatan yang dikeluarkan"

Jadi dapat disimpulkan bahwa dalam rangka mewujudkan asas pengelolaan keuangan desa yang transparan dan akuntabel, maka penatausahaan keuangan desa yang baik wajib dilaksanakan. Penatausahaan keuangan desa merupakan tanggung jawab bendahara desa. Permendagri No. 20 Tahun 2018 menyatakan bendahara desa wajib melakukan pencatatan setiap penerimaan dan pengeluaran, serta melakukan tutup buku setiap akhir bulan secara tertib. Bendahara desa bertanggung jawab untuk menciptakan suatu sistem pencatatan yang menghasilkan laporan keuangan yang benar, lengkap, akurat, andal, dan tepat waktu. Bendahara desa wajib mempertanggungjawabkan uang melalui laporan pertanggungjawaban yang disampaikan setiap bulan kepada kepala desa dan paling lambat tanggal 10 bulan berikutnya. Hal ini seperti yang diungkapkan oleh Anggriani, N., Iskandar, D., \& Nurodin, I. (2019) yang menyatakan bahwa dengan adanya penggunaan Sistem Keuangan Desa untuk pengelolaan Keuangan Pemerintah Desa seperti Buku Kas Umum, Buku Pembantu Pajak, Laporan Realisasi APBDes akan menjadikan pelaporan keuangan desa lebih akuntabel.

Penerapan Prinsip Responsibilitas, Akuntabilitas, Transparasi dan Partisipasi pada Tahap Pelaporan dan Pertangungawaban dalam Pengelolaan Keuangan Desa

Dalam melaksanakan tugas dan tanggungjawabnya dalam pengelolaan keuangan desa, Kepala desa memiliki kewajiban untuk menyampaikan laporan keuangan desa berupa, laporan keuangan periodik semesteran dan tahunan, yang disampaikan ke Bupati/Walikota dan ada juga yang disampaikan ke Badan Permusyawaratan Desa. Hal ini seperti yang diungkapkan Sekdes Kuala Alam, tanggal 07 April 2020, 08.00 WIB sebagai berikut:

"Kaur Keuangan akan membuat beberapa laporan keuangan yang tercantum di Permendagri 20 Tahun 2018. Pelaporan dan pertanggungjawaban ini merupakan satu rangkaian tahapan. Nantinya masing-masing Kaur dan Kasi akan membuat laporan pertanggungjawaban yang akan diserahkan kepada Kaur Keuangan"

Berdasarkan hasil wawancara dan pengamatan peneliti dalam penerapan prinsip Responsibilitas, Akuntabilitas, Transparasi dan Partisipasi pada tahap pelaporan menunjukkan bahwa pemerintah desa Kuala Alam sudah melaksanakan sesuai dengan ketentuan yang berlaku. Hal ini dapat dilihat bahwa kepala desa sudah membuat Laporan Realiasasi Pelaksanaan APBDesa, Laporan Pertanggungjawaban Realisasi Pelaksanaan APBDesa setiap akhir tahun anggaran dan Laporan Realisasi Penggunaan Dana Desa yang disampaikan kepada Bupati/Walikota melalui Camat. Kemudian juga sudah menyampaikan Laporan kepada Badan Permusyawaratan Desa (BPD) berupa Laporan Keterangan Pertanggungjawaban Realisasi Pelaksanaan APB Desa terdiri dari Pendapatan, Belanja, dan 


\section{Wahyuni, Fatmawati}

Penerapan Good Governance dalam Pengelolaan Keuangan

Desa Kuala Alam Kecamatan Bengkalis

Pembiayaan. Hal ini seperti yang diungkapkan BPD Kuala Alam, tanggal 06 April 2020, 14.00 WIB sebagai berikut:

"Untuk pertanggungjawaban pertama kita melaporkan ke Kabupaten. Kemudian kepada BPD selaku perwakilan masyarakat"

Bendahara Kuala Alam, tanggal 06 April 2020, 11.00 WIB, menambahkan:

"Dalam satu tahun itu jelas kita untuk Bendahara itu ditengah semester itu ada lapoaran setengah semester awal. Kemudian diakhir semester itu ada lagi laporan semester. Nah kemudian ada lagi yang global yaitu laporan realisasi APBDes tahun tersebut"

Dari hasil penelitian menunjukkan bahwa pemerintah desa Kuala Alam sudah memenuhi prinsip good governance. Hal ini ditunjukkan dalam memenuhi prinsip transparansi dan akuntabilitas, maka kepala desa Kuala Alam sudah menyusun dan menyampaikan laporan atas pelaksanaan tugas, kewenangan, hak, dan kewajibannya dalam pengelolaan keuangan desa. Laporan tersebut bersifat periodik semesteran/tahapan dan tahunan, yang disampaikan ke Bupati/Walikota, berupa: Laporan Realisasi Pelaksanaan APBDesa dan laporan realisasi penggunaan dana desa. Seperti hasil penelitian yang dilakuka oleh Astuti, Widayanti \& Damayanti (2021) bahwa proses pertanggungjawaban Kepala Desa yang disampaikan kepada Camat maupun Bupati tepat waktu melalui penyampaian laporan Realisasi Pengelolaan Dana Desa.

\section{KESIMPULAN}

Dari hasil penelitian tentang Penerapan Prinsip Responsibilitas, Akuntabilitas, Transparansi dan Partisipasi Pada Tahap Perencanaan, Pelaksanaan, Penatausahaan, Pelaporan dan Pertanggungjawaban dalam pengelolaan keuangan desa Kuala Alam dapat ditarik kesimpulan bahwa pengelolaan keuangan desa Kuala Alam sudah berjalan dengan baik yang dimulai dari (1). Tahap perencanaan dibuktikan dengan ada daftar hadir melaksanakan, keterbukaan dalam rapat, keterbukaan prosedur dan keterbukaan informasi mengenai perencanaan dan anggaran yang direncanakan oleh pemerintah desa Kuala Alam; (2). Tahap pelaksanaan, Kasi \& Kaur sudah menyerahkan dokumen untuk proses pencairan dana untuk satu kegiatan, adanya pemasangan papan proyek yang berisi rincian anggaran yang dikeluarkan serta adanya keterbukaan menerima peran masyarakat; (3). Tahap penatausahaan, dimana Bendahara Desa sudah melakukan pembukuan sesuai dengan kegiatan yang dilakukan; (4). Tahap pelaporan dan pertanggungjawaban, Pemerintah desa Kuala Alam sudah bertanggungjawab untuk menyampaikan laporan kepada BPD dan Bupati secara berkala. Dengan adanya penelitian ini diharapkan agar pemerintah desa Kuala Alam senantiasa melakukan koordinasi dan sosialisasi kepada pihak-pihak terkait agar program kegiatan yang akan dilakukan bisa lebih maksimal. Penelitian ini tidak terlepas dari berbagai keterbatasan, yaitu metodologi penelitian yang digunakan adalah case study, karena hasil analisa peneliti tergantung pada jawaban serta kejujuran responden dalam menjawab pertanyaan, sehingga kemungkinan bias sangat tinggi. Untuk peneliti berikutnya diharapkan untuk memperpanjang waktu penelitian agar setiap tahapan dalam pengelolaan keuangan desa dapat digali informasinya lebih banyak lagi. 


\section{DAFTAR PUSTAKA}

Agesta, Wulan. (2015) Responsibilitas Rumah Sakit Umum Daerah Dr. A. Dadi Tjokrodipo Kota Bandar Lampung. Fakultas Ilmu Social Dan Ilmu Politik. Universitas Lampung.

Andini, Hanni. (2018) Penerapan Prinsip Akuntabilitas dan Prinsi Tranparansi Dalam Pengelolaan Keuangan Desa. Program Study Akuntansi. Fakultas Ekonomi dan Bisnis Universitas Lampung.

Anggriani, N., Iskandar, D., \& Nurodin, I. (2019). Penerapan Prinsip Akuntabilitas dan Transparansi Dalam Pengelolaan Anggaran Pendapatan dan Belanja Desa. Jati: Jurnal Akuntansi Terapan Indonesia, 2(2), 59-64.

Astriandy, Christo (2018) Analisis Penerapan Good Goverment Governance Dalam Pengelolaan Keuangan Desa. Fakultas Ekonomi. Universitas Sanada Dharma Yogyakarta.

Badan Pengawasan Keuangan dan Pembangunan (2015) tentang Petunjuk Pelaksanaan Bimbingan dan Konsultasi Pengelolaan Keuangan Desa.

Bihamding, Hariawan (2019) Pengelolaan Keuangan Desa, Deepublish, Yogyakarta.

Ferarow, N. \& Suprihanto, J. (2018). Implementasi Pengelolaan Keuangan Desa Sumberadi dan Tlogoadi di Kabupaten Sleman: Evaluasi Praktik Transparansi dan Akuntabilitas. Jati: Jurnal Akuntansi Terapan Indonesia, 1(2), 64-69

Hikmahwati, Penti (2017) Metodologi Penelitian, Raja Grafindo, Depok

Mamudi, (2015) Manajemen Kinerja Sektor Publik, Edisi Ketiga, Cetakan Pertama. Yogyakarta: UPP STIM YKPN

Mardiasmo, (2009) Akuntansi Sektor Publik, Yogyakarta: Penerbit ANDI

M Irvan, Wayan I (2017) Penerapan Transparansi Pengelolaan Anggaran Pendapatan Dan Belanja Desa. Program Studi Ilmu Pemerintahan. Fakultas Sosial dan Politik. Universitas Lampung.

Sejerweni, V Wiratma (2014) Metodelogi Penelitian Pustaka Baru Press, Yogyakarta.

Sangki, dkk (2017. Penerapan Prinsip Transparansi Dan Akuntabilitas Dalam Pengelolaan Anggaran Pendapatan Dan Belanja Desa.

Undang-undang Nomor 6 Tahun 2014 tentang Desa.

Peraturan Pemerintah Nomor 43 Tahun 2014 tentang Peraturan pelaksanaan Undang-undang Nomor 6 Tahun 2014 tentang Desa.

Peraturan Menteri Dalam Negeri Nomor 20 tahun 2018 tentang Pengelolaan Keuangan Desa.

Yuliansyah, Rusmianto (2016). Akuntansi Desa, Jakarta Selatan: Penerbit Salemba 4.

Widiyanti, Arista (2017). Akuntabilitas dan Tranparansi Pengelolaan Keuangan Alokasi Dana Desa. Jurusan Akuntansi. Fakultas Ekonomi. Universitas Islam Negeri Maulana Malik Ibrahim Malang. 